\title{
The role of hematopoietic stem cell transplantation in the elderly patient with acute myeloid leukaemia
}

\author{
O papel do transplante de célula-tronco hematopoiética em pacientes idosos com \\ leucemia mielóide aguda
}

Attilio Olivieri $^{1}$

Monica Poggiaspalla ${ }^{1}$

Antonella Poloni ${ }^{2}$

\begin{abstract}
Older adults with Acute Myeloid Leukaemia (AML), when compared to younger patients with the same disease, have a poor prognosis and represent a discrete population in terms of disease biology, treatment-related complications, and overall outcome. As a result, older patients require distinctive management approaches. For $85 \%-95 \%$ of older AML patients, any therapy ultimately will be purely palliative. No randomized trial has ever demonstrated that any amount of post-remission therapy in older AML patients provides better outcomes than no post-remission therapy. The only studies demonstrating that long-term Disease Free Survival (DFS) is possible in older AML patients have included remission induction and post-remission therapy. For these reasons alternative post-remission strategies, including autologous or allogeneic transplantation have been explored also in people over sixty considered fit for aggressive therapy. Up to now the data available from clinical trials suggest that the stem cell transplant procedure is promising, and can lead to long-term survival, but it is feasible only in a minority of fit elderly patients. The main limits of Autologous Stem Cell Transplantation (ASCT) are represented by the low percentage of patients able to mobilize a sufficient amount of stem cells and by the still high relapse incidence after ASCT, especially in those with poor prognostic factors; for these patients the allogeneic transplant procedure, by using non myeloablative conditioning regimens, could offer a better chance of cure, thanks to the Graft versus Leukemia (GVL) effect, but there are no prospective trials showing the superiority of any transplant approach over conventional treatment in this subset of patients. Rev. bras. hematol. hemoter. 2008; 30(Supl. 2):37-41.
\end{abstract}

Key words: Autologous and allogeneic stem cell transplantation; acute myeloid leukaemia; elderly patients.

\section{Introduction}

Advances in the treatment of younger patients with AML have been obtained with intensified post-remission treatments, such as high-dose chemotherapy or allogeneic stem cell transplantation (HSCT). However, approximately half of patients with newly diagnosed AML are older than 65 years and thus are not eligible for such options. The biology of AML changes with age. When presenting in older study patients, AML was a less proliferative disease with lower white blood cell counts and peripheral blast percentages, the spectrum of cytogenetic abnormalities changed with a much higher incidence of abnormalities involving chromosomes 5 , 7 , and 17, a lower incidence of the translocations associated with favorable treatment outcomes, and the markedly increased incidence of p-glycoprotein expression. ${ }^{1-2}$ Also, patient performance status (PS) deteriorated with age; the effects of age both on the patient and the disease resulted in a higher incidence of death early after induction therapy, a lower rate of complete response (CR), and a lower chance for

${ }^{1}$ Dept. of Hematology, Ospedale San Carlo, Potenza, Italy.

${ }^{2}$ Dept. of Hematology, Università Politecnica delle Marche, Ancona-Italy.

Correspondence: Attilio Olivieri

Hematology Division, Ospedale San Carlo

85100 - Potenza-Italy

Tel +390971613660 Fax +390971613258

E-mail: attilio.olivieri@ospedalesancarlo.it 
long-term survival as the age of the patients increased. Factors related to age, including a poorer PS and comorbidities, may directly affect treatment tolerance. Factors related to disease biology, including more frequent prior myelodysplastic syndrome (MDS) and unfavorable karyotype, may lower the response rate and response duration..$^{3-7}$ In a recent large retrospective study, the outcome of elderly persons with AML was very poor, with a median survival of 2 months and a 2-year survival rate of $6 \%$; only $30 \%$ of them underwent chemotherapy treatment within 2 years after AML diagnosis. ${ }^{8}$

In summary the treatment of AML in older patients has not significantly improved in recent years and these patients still have a poor prognosis. Many studies have demonstrated that in these patients initial CR rates are around $45 \%$ to $55 \%$, and the relapse risk of remitters is around $80 \%$ to $85 \% .{ }^{9-10}$ Despite encouraging data from a recent German randomized study, suggesting the positive role of an intensive approach in these patients, ${ }^{11}$ in a more recent randomized trial, in which the 236 patients who reached CR were randomized for the postremission comparison, Gardin ${ }^{12}$ found that repeated courses of chemotherapy were associated with a longer time under treatment, while the ambulatory arm was associated with significantly shorter rehospitalization duration suggesting that, more prolonged ambulatory treatment should be preferred to intensive chemotherapy as postremission therapy in AML elderly patients.

However there is large agreemente about the fact that also in older patients, more effective induction therapy not only reduces the proportion of patients with resistant disease, but it can also improve remission duration. It has been reported that a dose-effect exists for Aracytin (ARAC) in AML, and that high-dose ARA-C prolongs remission duration and DFS when used as initial induction therapy in patients with de novo AML; moreover an intensive induction with chemotherapy such as DAT schedule, while not improving the remission rate, improves long-term survival. Unfortunately the increase of dose intensity in older patients is generally characterized by a substantial increase of the unacceptable toxicity in this setting of patients; furthermore the recent data coming from trials including the association of revertant drugs with chemotherapy, in order to improve both the $\mathrm{CR}$ rate and the OS have been disappointing. ${ }^{13-14}$

\section{ASCT as consolidation therapy in the elderly}

Despite no definitive data coming from prospective trials in this setting, at least $25 \%$ of the patients aged 60 to 70 years with de novo AML, can benefit from standard intensive treatment. In these patients, ASCT has a tolerable toxicity and may have a positive impact on leukemia-free survival. In some studies the intensification of remission including ASCT was feasible in elderly patients, but it is not clear if this approach could improve the general outcome in overall population.

Ferrara ${ }^{15}$ evaluated the feasibility of ASCT from 155 consecutive AML patients aged over 60 years (median age 72 years, range 61-94) programmed to receive ASCT by using peripheral blood stem cells (PBSC) after CR achievement. Overall, 90 out of 155 patients (58\%) were judged as eligible for aggressive chemotherapy and $45(50 \%)$ achieved CR. Among these, 36 (80\%) received consolidation and 32 were monitored for PBSC mobilization. A successful collection was registered in $25 / 32$ patients ( $50 \%$ of patients in CR). Finally, 20 patients received ASCT. Median survival (OS) was 4 months for the whole population and 19 months for patients actually autografted. Overall, 20 out of 90 patients accrued into intensive chemotherapy (22\%) and only 20 out of the entire patient population (13\%) underwent ASCT. Oriol assessed the proportion of patients over 60 years with de novo AML who qualified for intensive therapy and determined the feasibility and results of ASCT in $1^{\text {st }} \mathrm{CR}$. Over a 4-year period, 258 patients were registered of whom $135(52 \%)$ were enrolled for intensive treatment. The CR rate was $61 \%$. Only $27 \%$ of the potential candidates underwent ASCT. The probability of 2-year leukemia-free survival (LFS) after consolidation was $39 \%$ for these patients and $22 \%$ for candidate patients not undergoing ASCT $(\mathrm{p}=0.07)$.

We also evaluated the feasibility of a new regimen in 42 fit AML elderly patients, with High Dose Idarubicin plus HD ARA-C, and including Amifostine as cytoprotectant. We observed one treatment related death $(2 \%)$; the main extrahaematological toxicity was represented by grade IIIIV infections in $64 \%$ of patients. The overall response rate (ORR) was $83 \%$ and 32 patients received intensive consolidation therapy; 15 patients (48\%) were able to mobilize a sufficient number of CD34+ cells and 14 (33\% of the selected fit patients) were transplanted with PBSC. The 5 years OS was $19 \%$ with a median follow up of 38 months. Patients with unfavourable cytogenetic and those with secondary AML had poorer OS. ${ }^{16}$ Recently we updated these data and up to now we have observed 123 patients with non-M3 AML (median age 71 years; range 55-89). All patients were preliminary evaluated according to a simplified Multidimensional Geriatric Assessment, so we were able to separate fit patients from unfit or frail patients: 71 have been considered fit and were treated with the same protocol including High Dose Idarubicin plus High Dose-ARAC with Amifostine. Twenty seven (35\%) had AML secondary to myelodysplastic syndrome. Patients achieving CR were intended to receive a consolidation followed by PBSC collection and ASCT. Overall, 57 patients (73\%) achieved $\mathrm{CR}$; there were 5 induction deaths $(6 \%)$, while 16 patients were refractory $(21 \%)$. Forthy-eight patients remained in $\mathrm{CR}$ and received intensive consolidation therapy; among those 20 patients were able to mobilize a sufficient number 
of CD34+ cells and undergo ASCT. Six-year OS and LFS was $24 \%$ and $30 \%$ respectively, with a median follow-up of 29 months (range, 4-73). Patients with unfavourable cytogenetics and those with secondary AML had poorer OS; again in this experience about $40 \%$ of patients could mobilize a sufficient amount of PBSC for ASCT.

Finally a recent EORTC study evaluated ASCT after induction and consolidation in a more selected population of patients aged 61 to 70 years. The induction therapy was mitoxantrone, etoposide and ARA-C (MICE) with or without granulocyte colony-stimulating factor (G-CSF) during and/ or after chemotherapy: 61 patients were scheduled for PBSC harvest by leukapheresis, but PBSC were effectively harvested from 54 patients. For the whole group of 61 patients, the median DFS was 1.0 years and the 3 -year DFS rate was $21 \%$, while the OS was 1.4 years and the 3 -year OS rate was $32 \%$. A total of 26 patients could not be autografed and ASCT was performed in 35 patients following conditioning with the BAVC regimen. The median time for granulocyte recovery $>0.510 \mathrm{e} 9 / \mathrm{L}$ was 24 days and for platelets $>20 \times 10 \mathrm{e} / \mathrm{L}$ was 23 days following transplantation. After a median follow-up of 5.0 years from transplantation, the median DFS and OS were 1.1 and 1.6 years respectively, and the 3 -year rates of DFS and OS were $28 \%$ and $39 \%$ respectively. Eight autografted patients were still in continuous complete remission, 22 patients had relapsed and five had died in CR. ${ }^{17}$

\section{The role of allogeneic transplantation in the elderly}

Basing on the literature it could be concluded that ASCT can result in an improvement of therapeutic results in AML of the elderly, but it is feasible in a minority of selected patients and its efficacy seems to be very limited or any in those patients with unfavourable caryotipe.

Leukemia cell cytogenetics are the principal predictor of relapse-free survival time (RFS) in AML and remissions in patients with abnormal karyotypes, except inv(16), $\mathrm{t}(15 ; 17)$, or $\mathrm{t}(8 ; 21)$, are almost invariably brief; in this subset: indeed the median OS average is less than one year from CR date. Allogeneic hematopoietic stem cell transplantation (HSCT) in first complete remission (CR1) may extend RFS in such patients. ${ }^{18-19}$ However, the risk of transplant-related morbidity and mortality increases with age, such that conventional myeloablative conditioning is associated with considerable risk in patients older than 50 to 60 years. Since the median age of patients with AML and abnormal cytogenetics achieving first $\mathrm{CR}$ is 60 years, myeloablative HSCT is applicable to only a minority of these patients. Reduced-intensity conditioning (RIC) regimens are increasingly used in older patients; RIC regimens often allow older and debilitated patients to undergo HSCT. Several studies have shown outcomes and complication rates comparable with myeloablative HSCT in younger patients. Alyea ${ }^{20}$ performed a retrospective analysis of 152 patients older than 50 years undergoing RIC or myeloablative transplantation. Seventy-one patients received nonmyeloablative conditioning, fludarabine $\left(30 \mathrm{mg} / \mathrm{m}^{2} / \mathrm{d} \mathrm{x} 4\right)$ and intravenous busulfan $(0.8 \mathrm{mg} / \mathrm{kg} / \mathrm{d} \mathrm{x} 4) ; 81$ patients received myeloablative conditioning, primarily with cyclophosphamide and total body irradiation. RIC patients were more likely to have unrelated donors (58\% versus $36 \% ; P=.009)$, a prior transplant (25\% versus $4 \% ; P=<.0001)$, and active disease at transplantation $(85 \%$ versus $59 \% ; P=<.001)$. Despite the adverse characteristics, OS was improved in the RIC group at 1 year ( $51 \%$ versus $39 \%$ ) and 2 years ( $39 \%$ versus $29 \% ; P=.056)$. There was no difference in progression-free survival ( 2 years, $27 \%$ versus $25 \% ; P=.24$ ). The incidence of grade 2 to 4 graft-versus-host disease was similar (28\% versus $27 \%$ ). The non relapse mortality rate was lower for RIC patients ( $32 \%$ versus $50 \% ; P=.01$ ), but the relapse rate was higher ( $46 \%$ versus $30 \% ; P=0.052$ ). Sorror ${ }^{21}$ reported RIC results in patients with hematologic malignancies who were ineligible for conventional transplantations because of age, comorbidities, or both. The nonmyeloablative regimen consisted of $90 \mathrm{mg} / \mathrm{m}^{2}$ Fludarabine and 2 Gy total body irradiation given before and mycophenolate mofetil and cyclosporine given after HCT. This report compared, retrospectively, morbidity and mortality among 60 consecutive patients given RIC to those among 74 concurrent and consecutive patients given myeloablative conditioning (ablative patients) before unrelated HCT. The Charlson Comorbidity Index was used to assess pretransplantation comorbidities. Even though nonablative patients had significantly higher pretransplantation comorbidity scores, were older, and had more often failed preceding ablative transplantations and cytotoxic therapies, they experienced fewer grades III to IV toxicities than ablative patients. Further, the incidence of grades III to IV acute graft-versus-host disease (GVHD) was significantly lower in nonablative patients. Both patient groups had comparable 1-year probabilities of chronic GVHD. The 1year nonrelapse mortality rate was $20 \%$ in RIC patients compared to $32 \%$ in ablative patients (hazard ratio $=1.4$ ). After adjustment for pretransplantation differences between the 2 patient groups, the hazard ratio was $3.0(P=.04)$. Multivariate analyses showed higher pretransplantation comorbidity scores to result in increased toxicity and mortality. To prospectively assess the applicability of RICHSCT, Estey ${ }^{22}$ reported a trial in which all untreated patients 50 years or older with AML and unfavorable cytogenetics would be evaluated during induction for a possible RICHSCT in CR1. Ninety-nine of 259 patients entered CR. Fiftythree of the 99 were seen by the Transplant Service. A donor was identified for 26 patients (21 sibling, 5 unrelated) with RIC-HSCT performed in 14 (13 sibling). Results in consulted patients suggested that $50 \%$ or fewer of the 85 patients 
who did not undergo transplantation were potential transplant candidates. These data suggest a high likelihood (probability $>99 \%$ ) that, after accounting for age, cytogenetics and performance status, RFS and survival are longer in older patients if they undergo RIC-HSCT rather than chemotherapy in CR1.

In conclusion both ASCT and HSCT in AML elderly patients represents an important tool for CR1 consolidation after intensive chemotherapy. Unfortunately this kind of consolidation is feasible only in a minority of patients, being related to the high percentage of elderly unfit for aggressive approach. Another concern involves the role of ASCT with PBSC which is characterized by a shorter engraftment time, but also by a very high relapse incidence in those patients who can mobilize a good amount of PBSC, moreover even in case of a strong consolidation therapy, before ASCT, patients with secondary AML and with unfavourable caryotipe still have a very short DFS. The recent use of RIC allogeneic transplant in these patients can probably increase the OS, but only a minority of elderly patients can benefit from this approach. There is room for improvement in this setting, considering the opportunity to design new conditioning regimens (less toxic and with increased antileukemic activity) and better GVHD prevention, but the majority of elderly AML patients still remains an unsolved problem as these patients cannot be enrolled both in aggressive induction programs and in transplant (ASCT or HSCT) programs.

\section{Resumo}

Pacientes idosos com leucemia mielóide aguda (LMA), quando comparados com pacientes jovens com a mesma doença, apresentam prognóstico pobre e representam uma população particular em termos biológicos, complicações relacionadas ao tratamento e evolução clínica. Como resultado de tudo isto, o paciente idoso requer manuseio distinto. Para $85 \%-95 \%$ dos pacientes idosos a abordagem terapêtica será finalmente apenas paliativa. Nenhum estudo randomizado demonstrou qualquer vantagem de qualquer terapêutica na fase pós-remissão. Os únicos estudos que mostraram alguma vantagem em termos de sobrevida livre de doença em pacientes idosos portadores de LMA incluíram juntas as fases de indução e consolidação da remissão. Por estas razões, estratégias terapêuticas alternativas pós-remissão, incluindo transplante autólogo ou alogênico, têm sido exploradoras também em pacientes acima de 60 anos com boa performance status para as terapias de alta dose. Até agora, os dados disponíveis dos estudos clínicos sugerem que o procedimento usando célula-tronco é promissor e pode levar a sobrevida de longo prazo, porém factível apenas em uma minoria de pacientes idosos. Os principais limites para o transplante autólogo são representados pela baixa porcentagem de pacientes capazes de mobilizar suficiente quantidade de células-tronco e pela, ainda, alta incidência de recidiva após o transplante, principalmente em pacientes de fatores de mau prognóstico. Para o transplante alogênico, o uso de regimes de intensidade reduzida pode oferecer uma melhor oportunidade de cura graças ao efeito enxerto versus leucemia. Porém, não existem estudos clínicos comprovan- do a superioridade de qualquer modalidade de transplante em relação à terapia convencional. Rev. bras. hematol. hemoter. 2008; 30 (Supl. 2):37-41.

Palavras-chave: Transplante autólogo ou alogênico de célula-tronco; leucemia mielóide aguda; pacientes idosos.

\section{References}

1. Hiddemann W, Kern W, Schoch C, Fonatsch C, Heinecke A, Wörmann B, et al. Management of acute myeloid leukemia in elderly patients. J Clin Oncol. 1999;17:3569-76.

2. Grimwade D, Walker H, Harrison G, et al. The predictive value of hierarchical cytogenetic classification in older adults with acute myeloid leukemia (AML): analysis of 1065 patients entered into the United Kingdom Medical Research Council AML11 trial. Blood. 2001;98:1312-20.

3. Rowe JM. Treatment of acute myelogenous leukemia in older adults. Leukemia. 2000;14:480-7.

4. Estey EH. How I treat older patients with AML. Blood. 2004; 96:1670-3.

5. Appelbaum FR, Gundacker H, Head DR, et al. Age and acute myeloid leukemia. Blood. 2006;107:3481-5.

6. Fröhling S, Schlenk RF, Kayser S, Morhardt M, Benner A, Döhner $\mathrm{K}$, et al. Cytogenetics and age are the major determinants of outcome in intensively treated acute myeloid leukemia patients older than 60 years: results from the AMLSG trial AML HD98-B. Blood. 2006;108:3280-8.

7. Farag SS, Archer KJ, Mrozek K, et al. Pretreatment cytogenetics add to other prognostic factors predicting complete remission and long-term outcome in patients 60 years of age or older with acute myeloid leukemia: results from Cancer and Leukemia group B 8461. Blood. 2006;108:63-73.

8. Menzin J, Lang K, Earle CC, Kerney D, Mallick R. The outcome and costs of acute myeloid leukemia in the elderly. Arch Intern Med. 2002;162:1597-1603.

9. Goldstone AH, Burnett AK, Wheatley K, Smith AG, Hutchinson RM, Clark RE. Attempts to improve treatment outcomes in acute myeloid leukemia (AML) in older patients: the results of the United Kingdom Medical Research Council AML11 trial. Blood. 2001;98:1302-11.

10. Löwenberg B, Suciu S, Archimbaud E, et al. Mitoxantrone versus daunorubicin in induction-consolidation chemotherapy-the value of low-dose cytarabine for maintenance of remission, and an assessment of prognostic factors in acute myeloid leukemia in the elderly: final report of the leukemia cooperative group of the European Organization for the Research and Treatment of Cancer and the Dutch-Belgian Hemato-Oncology Cooperative Hovon group randomized phase III study AML-9. J Clin Oncol. 1998; 16:872-771.

11. Buchner T, Hiddemann W, Berdel WE, et al. 6-Thioguanine, cytarabine, and daunorubicin (TAD) and high-dose cytarabine and mitoxantrone (HAM) for induction, TAD for consolidation, and either prolonged maintenance by reduced monthly TAD or TADHAM-TAD and one course of intensive consolidation by sequential HAM in adult patients at all ages with de novo acute myeloid leukemia (AML): a randomized trial of the German AML Cooperative Group. J Clin Oncol 2003;21:4496-504.

12. Gardin C, Turlure P, Fagot T, Thomas X, Terre C et al. Postremission treatment of elderly patients with acute myeloid leukemia in first remission after intensive induction chemotherapy: results of the multicenter randomized Acute Leukemia French Association (ALFA) 9803 tial. Blood. 2007;109:5129-35. 
13. Lowenberg B, Zittoun R, Kerkhofs $\mathrm{H}$, et al. On the value of intensive remission induction chemotherapy in elderly patients of $65+$ years with acute myeloid leukemia: a randomized phase III study of the European Organization for Research and Treatment of Cancer Leukemia Group. J Clin Oncol. 1989; 7:1268-74.

14. Greenberg PL, Lee SJ, Advani R, et al. Mitoxantrone, etoposide, and cytarabine with or without valspodar in patients with relapsed or refractory acute myeloid leukemia and high-risk myelodysplastic syndrome: a phase III trial (E2995). J Clin Oncol. 2004;22:1078-86.

15. Ferrara F, Venditti A, Carellajr AM, Cantore N, Buccisano F, Tamburini A, et al. Autologous stem cell transplantation for patients with acute myeloid leukemia aged over 60 yr. Eur J Haematol. 2002;69:200-4

16. Olivieri A, Capelli D, Troiani E, Poloni A, Montanari M, Discepoli $\mathrm{G}$, et al. A new intensive induction schedale, including high-dose Idarubicin, high-dose Aracytin and Amifostine, in older AML patients: fasibility and long term results in 42 patients. Experim. Hematology. 2007;35:1074-82.

17. Thomas X, Suciu S, Rio B, Leone G, Broccia G, Fillet G, et al. Autologous stem cell transplantation after complete remission and first consolidation in acute myeloid leukemia patients aged 61-70 years: results of the prospective EORTC-GIMEMA AML13 study. Haematologica. 2007;92(3):389-96.

18. Burnett AK, Wheatley K, Goldstone AH, et al. The value of allogeneic bone marrow transplant in patients with acute myeloid leukaemia at differing risk of relapse: results of the UK MRC AML 10 trial. Br J Haematol. 2002;118:385-400.

19. Zittoun RA, Mandelli F, Willemze R, et al. Autologous or allogeneic bone marrow transplantation compared with intensive chemotherapy in acute myelogenous leukemia: European Organization for Research and Treatment of Cancer (EORTC) and the Gruppo Italiano Malattie Ematologiche Maligne dell'Adulto (GIMEMA) Leukemia Cooperative Groups. N Engl J Med. 1995; 332:217-23.
20. Alyea EP, Kim HT, Ho V, et al. Comparative outcome of nonmyeloablative and myeloablative allogeneic hematopoietic cell transplantation for patients older than 50 years of age. Blood. 2005;105:1810-4.

21. Sorror ML, Maris MB, Storer B, et al. Comparing morbidity and mortality of HLA-matched unrelated donor hematopoietic cell transplantation after nonmyeloablative and myeloablative conditioning: influence of pretransplant comorbidities. Blood. 2004;104:961-8.

22. Estey E, de Lima M, Tibes R, et al: Prospective feasibility analysis of reduced intensity conditioning regimens for hematopoietic stem cell transplantation (HSCT) in elderly patients with acute myeloid leukemia and high-risk myelodysplastic syndrome. Blood. 2007; 109:1395-1400.

O tema apresentado constou do programa do Encontro AIBE. Avaliadores: Professores Ângelo Maiolino, Cármino Antonio de Souza e Marcio Nucci.

Publicado após concordância do editor.

Conflito de interesse: não declarado.

Recebido: 09/05/2008

Aceito: 20/05/2008 